\title{
Knowledge and Industry Clusters as Drivers of Economic Development and Competitiveness
}

\section{Знање и индустријски кластери као покретачи економског развоја и конкурентности}

\author{
Сандра Једнак* \\ Универзитет у Београду, Факултет организационих наука, Београд \\ Драгана Крагуљ ${ }^{* *}$ \\ Универзитет у Београду, Факултет организационих наука, Београд \\ Милош Парежанин ${ }^{* * *}$ \\ Универзитет у Београду, Факултет организационих наука, Београд
}

\begin{abstract}
The aim of this paper is the analysis of knowledge and clusters as drivers of economic development and competitiveness. A theoretical overview of the knowledge and clusters development will be provided. The overview of indicators (economic growth, GDP per capita, unemployment, GCl, Innovation Indexes) will be given, and the findings based on the indicators will be discussed for EU candidate countries. Correlation between cluster development and competitiveness will be analysed. Knowledge and clusters are drivers of economic development and competitiveness, but they are not the key factors in those countries. Other factors have more effect on development and competitiveness. Limitation of the paper is a lack of the empirical studies and data of observed countries. Further research will be oriented to a particular sector and one country from EU candidate countries.
\end{abstract}

Keywords: knowledge, clusters, economic development, competitiveness

Сажетак: Циљ овог рада је анализа знања и кластера као покретача економског развоја и конкурентности. Биће приказан теоријски преглед развоја заснованог на знању и кластеру. Даћемо и преглед индикатора (економски раст, БДП по глави становника, незапосленост,ГЦИ, индекси иновација), а резултати на основу индикатора биће разматрани за земље кандидате за чланство у ЕУ. Анализираће се корелација између развоја кластера и конкурентности. Знање и кластери су покретачи економског развоја и конкурентности, али они нису кључни фактори у посматраним земљама. Други фактори имају већи утицај на развој и конкурентност. Ограничење рада је недостатак емпиријских студија и података посматраних земаља. Будуће истраживање биће усмерено на одређени сектор и једну од земаља кандидата за чланство у ЕУ.

Кључне речи: знање, кластер, економски развој, конкурентност.

\footnotetext{
* $\bowtie$ sjednak@fon.bg.ac.rs

** $₫$ kragulj@fon.bg.ac.rs

*** $\bowtie$ parezanin.milos@fon.bg.ac.rs
} 


\section{Introduction}

Knowledge has always been one of the main drivers of development. Due to the EU aim to become a knowledge-based economy, knowledge has become even more important. Efficient creation, dissemination and use of knowledge lead to knowledgebased development, economy and competitiveness (Jednak et al., 2015; Parezanin et al., 2014). Investing in education, research and development, and innovation has become important for obtaining knowledge driving development. However, there are other ways that can lead to the increase in productivity and innovation. Some policies and strategies are based on the regional development that will push up the economy. One of the policies is the establishment of clusters i.e. "a collaboration between different enterprises based on the size, geographic position and industry" (Porter, 1998). The cluster represents a way to increase competitiveness and economic development through innovation by applying knowledge, research and development and new technologies. In the cluster, interactions, sharing of facilities and knowledge exchange are of great importance. This contributes to networking, transfers and dissemination of information, knowledge and technology (Edler et al., 2016; Tadeo et al., 2017). That should provide economic growth and development.

The scope of the paper is a theoretical overview of the knowledge-based and clusters-oriented economic development. The central research question is whether the relationship between knowledge and cluster can lead to competitiveness and economic development. The aim of the paper is to analyse the influence of cluster and knowledge on economic growth, employment, GDP per capita and competitiveness.

The paper is structured as follows: after the Introduction, Section 2 provides a theoretical overview of knowledge and cluster-based development. Section 3 provides the summary of the cluster, knowledge and economic development in the EU candidate countries, as well the relation between competitiveness and cluster development. Concluding remarks are provided in the last section.

\section{Knowledge- and clusters- based economic development}

Different approaches and strategies are possible for obtaining development. According to Lisbon strategy (2000) and Europe 2020, development and competitiveness rely on knowledge. In the recent years, the cluster oriented strategy has been seen as a suitable approach for obtaining local, regional and economic development (Desrochers \& Sautet, 2004).

\subsection{Knowledge-based development}

In modern economic theory, knowledge is the key factor of economic growth and development. New ideas, skills and competencies are the results of the knowledge that 
will be built into new products, processes and organisational structure of the company. Schumpeter is the first who recognised knowledge as a structural component and its role in the economic development. He claimed that knowledge is the essential factor of innovation and entrepreneurship (Cook, 2005).

Globalisation, Lisbon strategy (2000) and Europe 2020 set the focus on obtaining the competitiveness and knowledge-based economy. Governments of advanced economies tend to carry out structural reforms and run policies that promote innovative and competitive knowledge-based economy (Sum and Jessop, 2013). In such economies, knowledge-intensive activities are a primary source of economic growth (Strulic et al., 2013) because they create, circle, disseminate and apply the knowledge which supports economic growth. The knowledge-intensive activities are: a) education, b) research and development, c) art, the media, information sector and d) information technologies. Synergy among education, knowledge and human capital enables the progress and the knowledge-based economy. Besides, openness is necessary for entrepreneurship and company's growth (Jeraj et al., 2015). Furthermore, the integration of education, science (R\&D) and information technology has become a valuable input for the development. Depending on the economic activity, knowledge is analysed as production (research and development of new knowledge), transmission (education and training) and transfer (diffusion of knowledge and innovation). Knowledge could be both input and final product. Besides, knowledge as a factor is an investment in research and development, education and information technology. As a product, knowledge influences development of knowledge-based business services. It is applied to improve existing products and create new ones.

According to the Lisbon Strategy (2000), development could be achieved by investments in education, R\&D and innovation. Furthermore, Europe 2020 is the EU growth strategy for a smart, sustainable and inclusive growth that leads to higher productivity, employment and social cohesion (European Commission, 2010). According to some organisations, knowledge-based development is a combination of both sustainable development and knowledge-based management. Some advanced economies create more GDP from knowledge-based activities than from industry and agriculture. Promotion of competitiveness and knowledge-based economy, as well as innovation policy, leads to cluster development.

\subsection{Cluster-based economic development}

Clusters could improve regional economic performance and competitiveness (Porter, 1998; Giuliani, 2005; Desrochers \& Sautet, 2004; Fayyaz et al., 2015). Their aim is to provide synergetic potential from all enterprises and institutions in the cluster due to efficiently completed economic/business process or project. Clusters reduce costs of supplies, decrease raw material stocks, exchange knowledge and influence job creation, skilled labour force, diffusion of technology, innovations, enlargement of the market and business opportunities (Boronenko \& Zeibote, 2011; Delgado et al., 2014; 
Sosnovskikh, 2017). The cluster is one of the policy tools for achieving economic development and competitiveness. Clusters are the engine of innovation that boosts productivity and prosperity.

Porter (2001) argues that clusters are not developed in developing countries. The aim of developing countries is integration in the global market. To achieve that objective, the cluster is one of the drivers for obtaining competitiveness. However, in those countries formation of the cluster is on the basic level due to lack of education, technology, infrastructure, the openness of the capital markets, investments and undeveloped institutions. Creation of clusters enhances the internal/domestic and then regional trade (Porter, 2001). Research studies about clusters can have focused on the technology, local/regional industry development (Delgado et al., 2014) or economic development (Taddeo et al., 2017a).

Some clusters are the result of organising and interaction among more enterprises due to business processes and market, while others are the product of national and regional cluster funding programs that are related to the region and similar activities. According to this, it is possible to make classification of clusters into the industry (if the enterprises are functionally organised) and regional clusters (if they are connected due to the region). Industrial clusters consist of entities and activities associated with developing, producing and selling products and services. They are not limited to a local zone, but could cover a whole country. Old industry clusters were oriented on manufacturing, while today's industry clusters "combine services with technology and/or high value added production" (Stimson et al., 2006). Their focus is on increasing competitiveness in different sectors, especially of export oriented companies. These clusters have had a role in obtaining industrial development in the regions of the developing countries (Giuliani, 2005). They have influenced the development of trade, regional and economic development. Furthermore, regional or local clusters represent area agglomeration of enterprises and other entities that perform the same or similar economic activities, spreading knowledge and creating various forms of learning (Boronenko \& Zeibote, 2011). That should lead to regional development. These clusters usually consist of small and medium enterprises. Their success is primarily conditioned by geographical proximity.

Governments have to establish an industry/cluster policy and to generate, transfer and diffusion of knowledge due to obtaining innovations which will improve companies, industry and regional performances and development (Humphrey \& Schmitz, 2002). Cluster policy, program and initiatives are oriented towards networking and training, promotion of export and supply chain development. The purpose of cluster initiatives is to promote development by involving enterprises, governments and other entities for joint activities in the leading national industries. ICT and tourism clusters exist in all countries. Synergies and cooperation among small, medium and large enterprises and other entities bring national sector/industry competitiveness and specialisation. Interaction, exchange of knowledge among entities 
and skilled labour force in the cluster enable the increase of sector competitiveness and development that attract foreign direct investments. Therefore, clusters are seen as a possibility for attracting foreign capital that is a major source of the economic growth. Furthermore, with horizontal industry policy, SMEs are in focus. Following the Italian model of development, based on industrial districts, networking and clustering of SME in specific geographic location are important for regional and economic development (Bartlett, 2014). Regional development is important for EU candidate countries, because they have to improve development and competitiveness of their lagging regions (Lengyel, 2009). In developing and transition countries, clusters have usually been created in agriculture and basic industries, while in advanced countries clusters are established in high tech industries (Ketels et al., 2006). Moreover, innovation clusters are based on knowledge and innovation and they continually improve activities in the cluster based on the market forces. Development of clusters is mostly based on the investment in education and sources of funding. Besides, these clusters are in the area of growing industry/sector such as information communication technologies, multimedia and biotechnology, etc. Based on the new growth theory on innovation, globalisation and higher competition, knowledge based and growing industries established in clusters can enhance growth and development.

Higher job creation and patenting growth, complementarity between employment and innovation performance could be obtained in a strong cluster (Delgado et al., 2014). Cluster-based development policies are created in a way that covers many dimensions critical for enterprise success, and they encourage the competition among companies for innovation and growth (Ketels and Memedovic, 2008). In that way competitiveness increases, while jobs and wages maintain or rise. Cluster development influences the regional development and subsequent economic development due to collaborations among government agencies and institutions, enterprises, university and research institutions.

\section{Economic and cluster development in EU candidate countries}

EU candidate countries have been the economies in the transition process. They have carried out economic reform and full fielded conditions to join the EU (Kragulj, 2015). Higher productivity, competitiveness and innovation are the objective of many European countries. However, some of the regions are not at the same level of the development. Increasing regional development is based on the cluster development. Even EU candidate countries are lagging behind the EU; those countries have to fulfil the same objective. Their economic development strategy is mostly based on the macroeconomic level, less than to the microeconomic level i.e. clusters. Even so, those countries have been enhancing competitiveness and development through knowledge and innovation attracting investments due to low costs. Geographical specialisation in 
the appropriate business environment and stable macroeconomic policy brings productivity growth and prosperity. SMEs have a role in business activities, and they are seen as a driver for developing economies. Cluster development should have a direct or indirect impact on economic growth rate, GDP per capita, and unemployment. Cluster development is shown by numbers of companies, employment, wages, value added, productivity in the cluster, cluster specific export. However, these data are not available for EU candidate countries. This is a limitation of making an appropriate analysis of cluster development and its influence on economic development and competitiveness. Therefore, observed indicators have been selected to overview an economic development in observed countries (Figures 1-3).

Figure 1. GDP growth (annual \%), EU candidate countries, 2011-2016

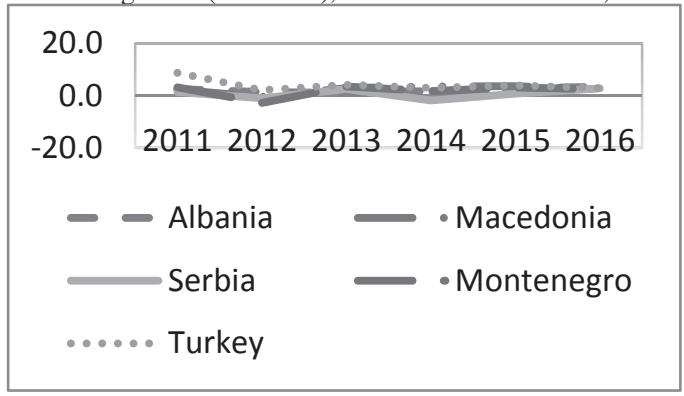

Source: The World Bank data

Figure 2. GDP per capita (current US\$), EU candidate countries, 2011-2016

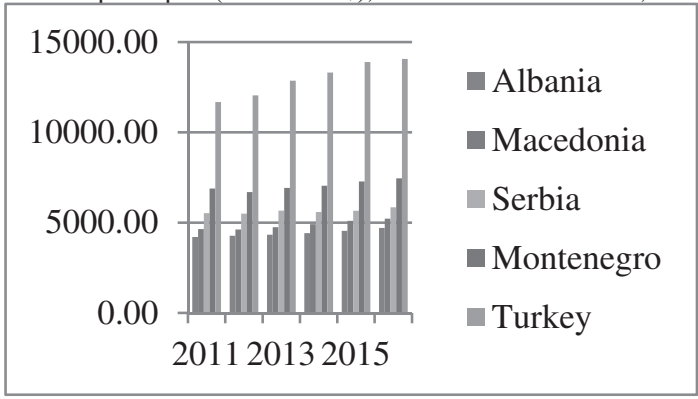

Source: The World Bank data 
Figure 3. Unemployment, total (\% of total labour force) EU candidate countries, 2011-2014

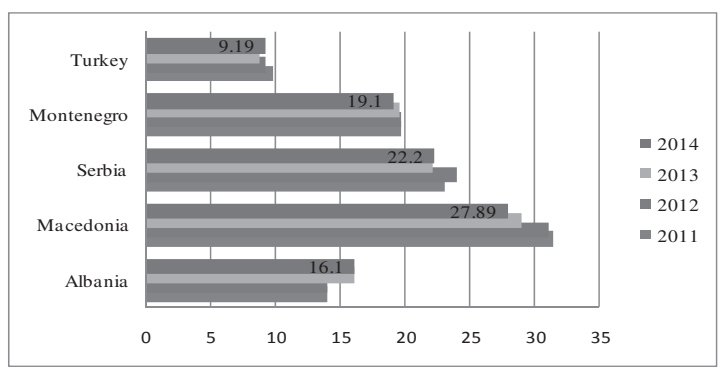

Source: The World Bank data

EU candidate countries have economic issues due to reforms, global economic crisis, euro zone crisis and fulfilment of EU conditions. Economic growth rates drop in 2012 because of consumption and investment decrease. After that, all the countries except Serbia underwent recovery and an increase in GDP. In 2014, Serbia had floods that influenced lower economic growth rate. Unemployment is a serious problem, except for Turkey. Macedonia has nearly $28 \%$ unemployment rate; Serbia and Montenegro have about $20 \%$. Unemployment is an issue for all the countries. The problems started with the transition process, reconstruction and privatisation of public companies, and become even bigger by the economic crisis. The standard of living does not fluctuate much for the given period. In 2016, GDP per capita was \$3945 in Albania, \$4852 in Macedonia, \$5235 in Serbia and \$6406 in Montenegro. Turkey has the highest GDP per capita - \$9125 (The Word Bank data, 2017). There is industry production stagnation. Due to this issue, policies are based mostly on attracting foreign capital and less on the establishing clusters.

Tables 1 and 2 show selected indicators that present competitiveness in EU candidate countries.

Table 1: Innovation Indexes for EU candidate countries

\begin{tabular}{|l|c|c|c|c|c|c|c|c|}
\hline & \multicolumn{6}{|c|}{ European Summary Innovation Index (0 to 1) } & \multicolumn{3}{|c|}{$\begin{array}{c}\text { Global Innovation Index } \\
\text { (average) rank, 1st rank is } \\
\text { the best }\end{array}$} \\
\hline & $\mathbf{2 0 1 1}$ & $\mathbf{2 0 1 2}$ & $\mathbf{2 0 1 3}$ & $\mathbf{2 0 1 4}$ & $\mathbf{2 0 1 5}$ & $\mathbf{2 0 1 4}$ & $\mathbf{2 0 1 5}$ & $\mathbf{2 0 1 6}$ \\
\hline Albania & n.a. & n.a. & n.a. & n.a. & n.a. & 94.00 & 87.00 & 92.00 \\
\hline Montenegro & n.a. & n.a. & n.a. & n.a. & n.a. & 59.00 & 41.00 & 51.00 \\
\hline Serbia & 0.231 & 0.251 & 0.318 & 0.309 & 0.325 & 67.00 & 63.00 & 65.00 \\
\hline Macedonia & 0.207 & 0.202 & 0.207 & 0.211 & 0.220 & 60.00 & 56.00 & 58.00 \\
\hline Turkey & 0.199 & 0.202 & 0.199 & 0.205 & 0.267 & 54.00 & 58.00 & 42.00 \\
\hline
\end{tabular}

Source: Global Innovation Index, European Innovation Scoreboard 
Table 2: Global competitiveness index (GCl) EU candidate countries

\begin{tabular}{|l|c|c|c|c|c|}
\hline GCR 2015-16 & $\mathbf{2 0 1 2 - 1 3}$ & $\mathbf{2 0 1 3 - 1 4}$ & $\mathbf{2 0 1 4 - 1 5}$ & $\mathbf{2 0 1 5 - 1 6}$ & $\mathbf{2 0 1 6 - 1 7}$ \\
\hline Albania & $89 / 144$ & $95 / 148$ & $97 / 144$ & $93 / 140$ & $80 / 138$ \\
\hline Montenegro & $72 / 144$ & $67 / 148$ & $67 / 144$ & $70 / 140$ & $82 / 138$ \\
\hline Serbia & $95 / 144$ & $101 / 148$ & $94 / 144$ & $94 / 140$ & $90 / 138$ \\
\hline Macedonia & $80 / 144$ & $73 / 148$ & $63 / 144$ & $60 / 140$ & $68 / 138$ \\
\hline Turkey & $43 / 144$ & $44 / 148$ & $45 / 144$ & $51 / 140$ & $55 / 138$ \\
\hline
\end{tabular}

Source: Global Competitiveness Reports, Global Innovation Index, European Innovation Scoreboard

Global innovation index shows that Montenegro and Turkey have the best rank, while Serbia and Macedonia follow them. According to European Innovation Scoreboard (2016), Serbia and Turkey are moderate innovators, while Macedonia is a modest one. Macedonia and Turkey have the highest rank of competitiveness (Global Competitive Index - GCI).

Due to level of economic development, clusters can have large or little influence on achieving further development of countries. Clusters have an impact on the EU economic development and competitiveness (Innova \& INNO, 2008; Ion \& Cristina, 2013; Bordei, 2016). In the EU, clusters correlation between employment and higher wages is significant, thus providing increased productivity and growth. According to EU Cluster portal (2017), 38 \% of European jobs are based in clusters, $33.3 \%$ of enterprises in the cluster increases employment to $10 \%$ (2010-2013). As previously mentioned, other benefits of the industry cluster development are: 1) reconstruction, an increase of manufacturing, 2) encouraging the SMEs and entrepreneurship, 3) higher competitiveness and exports and 4) regional development. If an economy has a high level of development, then the cluster is more developed, and enterprises in the cluster obtain better economic and business performances. Furthermore, in advanced countries, there is a focus on innovation and knowledge creation. Therefore, clusters are more developed in EU than in other developing countries like EU candidate countries. In advanced economies, clusters have mainly focused on the building identity, strategy and brand trough and increase innovation thought the collaboration, and less to the export, commercial cooperating and joint purchasing (Ketels et al., 2012).

EU candidate countries (Albania, Montenegro, Serbia, Macedonia and Turkey) are at the beginning of developing cluster policies. There is a certain progress, but it is still far from the development in advanced economies. Most of the countries are still undergoing the initial phases of cluster development. Cluster development program started in the mid 2000s as a pilot project funded by governments and international institutions. Only Turkey began with industrial agglomeration in the 1980s to develop the industry to increase export. Figure 4 presents the state of cluster development in EU 
candidate countries according to Global Innovation Index. In 2016, Turkey held the best position - it ranked 50 out of 128 countries, Serbia ranked 103 out of 128 countries, and Albania held the lowest position.

Figure 4. State of cluster development EU candidate countries (rank) 2014-2016

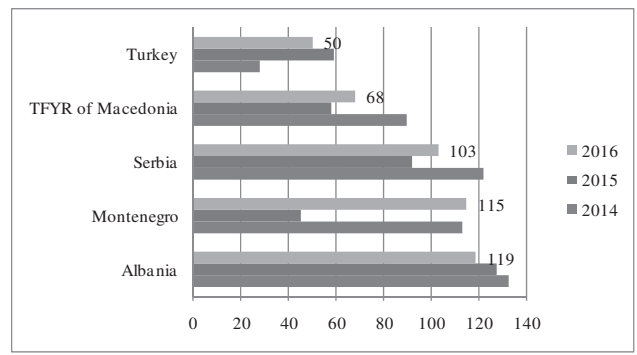

Note: best position is 1 . Source: Global Innovation Index

SMEs are vital for Serbian economy. According to Minovic et al. (2017), SMEs are focused on costs as a source of competitive advantage, but they are innovation-oriented. Middle size enterprises are oriented to process innovations, while small size enterprises are focused on product innovations. SMEs make up to $99.8 \%$ of total active enterprises; employing more than $2 / 3$ of employees and contributing to more than 30\% of GDP in Serbia (Rakicevic et al., 2016). However, SMEs face certain obstacles: lack of information, knowledge, management skills, funding, technology, infrastructure, etc. To overcome that, SMEs should make collaborations and form clusters. Even so, less than $2 \%$ of domestic enterprises are involved in clusters, and $3 \%$ of the labour force is employed. There are less than 60 clusters in Serbia. Most clusters are in automotive, ICT, agricultural, wood and metal processing industry. Table 3 shows the available data on clusters in Serbia (Cluster Observatory, 2017).

Table 3. Data about cluster in Serbia, 2011

\begin{tabular}{|l|c|c|c|c|c|c|c|}
\hline Sector & $\begin{array}{c}\text { Employees } \\
\text { in sector }\end{array}$ & $\begin{array}{c}\text { Enterprises } \\
\text { in sector }\end{array}$ & $\begin{array}{c}\text { Employment } \\
\text { per } \\
\text { enterprises }\end{array}$ & $\begin{array}{c}\text { Observatory } \\
\text { star rating }\end{array}$ & Size & Specialisation & Focus \\
\hline Agricultural products & 13873 & 1733 & 8 & 1.87 & 1.63 & 2.23 & 1.16 \\
\hline Apparel & 23151 & 5264 & 4.4 & 1.07 & 1.94 & 2.65 & 1.93 \\
\hline Automotive & 19895 & 985 & 20.2 & 1.26 & 0.91 & 1.24 & 1.66 \\
\hline $\begin{array}{l}\text { Building fixtures, equipment and } \\
\text { services }\end{array}$ & 25320 & 5354 & 4.7 & 1.15 & 1.34 & 1.83 & 2.11 \\
\hline Business services & 15200 & 8595 & 1.8 & 0 & 0.23 & 0.32 & 1.27 \\
\hline Construction & 56510 & 9320 & 6.1 & 1 & 0.86 & 1.17 & 4.72 \\
\hline Distribution & 26768 & 6425 & 4.2 & 1.11 & 1.22 & 1.66 & 2.23 \\
\hline Farming and animal husbandry & 12580 & 2002 & 6.3 & 0.39 & 1.32 & 1.81 & 1.05 \\
\hline
\end{tabular}




\begin{tabular}{|l|c|c|c|c|c|c|c|} 
Financial services & 28837 & 1973 & 14.4 & 0.74 & 0.53 & 0.72 & 2.41 \\
\hline IT & 9138 & 2578 & 3.5 & 0 & 0.59 & 0.8 & 0.76 \\
\hline Metal manufacturing & 40596 & 6148 & 6.6 & 1.4 & 1.22 & 1.66 & 3.39 \\
\hline Paper products & 15119 & 3885 & 3.9 & 0.34 & 1.19 & 1.63 & 1.26 \\
\hline Processed food & 83027 & 12899 & 6.4 & 1.77 & 2.03 & 2.77 & 6.93 \\
\hline Telecom & 14433 & 1129 & 12.7 & 0 & 0.86 & 1.17 & 1.2 \\
\hline Textiles & 12497 & 1842 & 6.8 & 0.67 & 1.52 & 2.08 & 1.04 \\
\hline Tourism and hospitality & 23714 & 18503 & 1.3 & 0 & 0.82 & 1.12 & 1.98 \\
\hline Transportation and logistics & 23410 & 1467 & 15.9 & 0 & 0.49 & 0.67 & 1.95 \\
\hline
\end{tabular}

Sectors with the highest employment are Processed food (83027) and Metal manufacturing (40596). The largest number of enterprises is in Processed food and Tourism and hospitality sectors. Cluster Observatory has a methodology named star rating $(0,1,2$ and 3$)$, where the number of stars depends on how many criteria (size, specialisation, focus) are fulfilled. If only one criterion is met, the star is 1 . Size measures whether a cluster is in the top $10 \%$ of total EU clusters. Specialisation shows the particular cluster category i.e. its specialisation. Focus measures a share of total employment in the region. Serbia has less than 2 stars in all sectors. Agriculture products sector has 1.87, while processed food sector has 1.77 stars. These results indicate that Serbia should put more effort in cluster development.

There are different levels of cluster development in Serbia. In the first stage, there is $20 \%$ of the cluster, $30 \%$ in the second stage (stage of initial operation), $20 \%$ in the third stage (growth commercialization) and $30 \%$ in sustainable stage of growth (the fourth stage). Clustering is at an unacceptable level. Cluster policy shows a reduced implementation and has little impact on economic growth. Cluster development needs to be promoted and implemented in national strategy documents.

According to Paraušić et al. (2014), "a high positive correlation exists between cluster development and national competitiveness". They have found that clusters affect positively national competitiveness in developing countries. Cluster based development improve productivity and innovation so the competitiveness too. In order to explore whether there is any connection between competitiveness and cluster development, a correlation is calculated. Competitiveness is measured by Global Competitiveness Index - GCI (1 lowest -7 highest), and cluster development by State of cluster development (1 lowest -7 highest) from The Global Competitiveness Report 2015-2016. There is a hypothesis that a linear correlation exists between cluster development and competitiveness. Based on the data, the results are shown in Table 4. 
Table 4. Correlations between State of cluster development and GCI, EU candidate countries, 2015-2016

\begin{tabular}{|l|l|r|r|}
\hline & & $\begin{array}{r}\text { State of cluster } \\
\text { development }\end{array}$ & GCI \\
\hline State of cluster development & Pearson Correlation & 1 & 0.787 \\
\hline & Sig. (2-tailed) & 5 & 0.114 \\
\hline GCI & $\mathrm{N}$ & 0.787 & 5 \\
\hline & Pearson Correlation & 0.114 & 1 \\
\hline & Sig. (2-tailed) & 5 & 5 \\
\hline
\end{tabular}

Source: The Global Competitiveness Report 2015-2016

There is a correlation between State of cluster development and GCI (Global Competitiveness Index) in EU candidate countries. The Pearson correlation coefficient (r) is 0.787 and shows a strong positive correlation between these two variables, but is not statistically significant due to $\mathrm{p}$ value $(\mathrm{p}=0.114)$. Sample size affects $\mathrm{p}$ value, but not the correlation. High $p$ value (0.114) could be the result of small sample size (5). However, when all 140 countries from The Global Competitiveness Report 2015-2016 are observed, results are different due to larger sample size (140) (Table 5).

Table 5. Correlation between State of cluster development and GCI, 2015-2016

\begin{tabular}{|l|l|r|r|}
\hline & & \multicolumn{1}{|c|}{$\begin{array}{c}\text { State of cluster } \\
\text { development }\end{array}$} & GCI \\
\hline State of cluster development & Pearson Correlation & 1 & $0.810^{* *}$ \\
\hline & Sig. (2-tailed) & 140 & 0.000 \\
\hline GCI & $\mathrm{N}$ & $0.810^{* *}$ & 140 \\
\hline & Pearson Correlation & 0.000 & 1 \\
\hline
\end{tabular}

** Correlation is significant at the 0.01 level

There is a statistically significant strong positive correlation between State of cluster development and GCI (Global Competitiveness Index), the Pearson correlation coefficient, $\mathrm{r}=0.787, \mathrm{p}<0.01$. With this sample size (140) the research hypothesis is accepted, there is linear correlation exists between cluster development and competitiveness.

\section{Conclusion}

There are different growth and development strategies, as well as strategies for increasing competitiveness. Knowledge and innovation are drivers of development in 
modern economies. Porter (1998) has claimed that cluster is a factor of the regional development. Due to that theory, the cluster has become a policy tool for obtaining competitiveness and development in various countries. Positive effects of clusters are: exchange knowledge, job creation, skilled labour force, diffusion of technology, innovations, enlargement of the market and business opportunities, (Boronenko \& Zeibote, 2011; Delgado et al., 2014; Sosnovskikh, 2017) increase of manufacturing, encouraging the SMEs and entrepreneurship, higher competitiveness and exports and regional development. Clusters have an impact on the EU economic development and competitiveness (Innova \& INNO, 2008; Ion \& Cristina, 2013; Bordei, 2016). In the EU countries, cluster development is at the highest level, while in EU candidate countries it is still at a low level. In EU candidate countries the relationship between knowledge and cluster could lead to a regional development. However, even though cluster and knowledge are implied in the development strategy of EU candidate countries, they do not have a significant influence on competitiveness and development. Still, due to the closing gap and lagging to the EU, these countries established industry/cluster policy to encourage collaboration among SMEs, governance agencies, university and research institutions that will create knowledge and innovations that increase productivity and prosperity of regions and nation.

\section{References}

Bartlett, W. (2014). Shut Out? South East Europe and the EU's New Industrial Policy. Browser Download This Paper.

Bordei, C. (2016). Clusters-Sources Of Economic Growth In Europe. SEA-Practical Application of Science, (10), 141-148.

Boronenko, V., \& Zeibote, Z. (2011). The potential of cluster development and the role of cluster support policies in Latvia. Economic Annals, 56(191), 35-67.

Cooke, P., \& Leydesdorff, L. (2006). Regional development in the knowledge-based economy: The construction of advantage. The Journal of Technology Transfer, 31(1), $5-15$.

Delgado, M., Porter, M. E., \& Stern, S. (2014). Clusters, convergence, and economic performance. Research Policy, 43(10), 1785-1799.

Desrochers, P., \& Sautet, F. (2004). Cluster-based economic strategy, facilitation policy and the market process. The Review of Austrian Economics, 17(2), 233-245.

Edler, J., Cunningham, P., \& Gök, A. (Eds.). (2016). Handbook of Innovation Policy Impact. Edward Elgar Publishing.

EU Cluster portal (2017). Cluster portal. Retrivied from https://ec.europa.eu/growth/smes/cluster_en 
European Commision (2010). Europe 2020. Retrieved from http://ec.europa.eu/europe2020/index_en.htm

Fayyaz, A., Lund-Thomsen, P., \& Lindgreen, A. (2015). Industrial clusters and CSR in developing countries: the role of international donor funding. Journal of Business Ethics, 1-19.

Giuliani, E. (2005). Cluster absorptive capacity: why do some clusters forge ahead and others lag behind?. European urban and regional studies, 12(3), 269-288.

Humphrey, J., \& Schmitz, H. (2002). How does insertion in global value chains affect upgrading in industrial clusters?. Regional studies, 36(9), 1017-1027.

Innova, E., \& INNO, P. (2008). The concept of clusters and cluster policies and their role for competitiveness and innovation: main statistical results and lessons learned. Europe paper, (9).

Ion, P., \& Cristina, V. (2013). Cluster policies in the European Union-Engines for sustainable economic development and competitiveness. THE ANNALS OF THE UNIVERSITY OF ORADEA, 1581.

Jednak, S., \& Kragulj, D. (2015). Achieving sustainable development and knowledgebased economy in Serbia. Management: Journal of Sustainable Business and Management Solutions in Emerging Economies, 20(75), 1-12.

Jeraj, M., Marič, M., Todorović, I., Čudanov, M. \& Komazec, S. (2015). The Role of Openness and Entrepreneurial Curiosity in Company's Growth. Amfiteatru Economic Journal, XVII(38).

Ketels, C. H., \& Memedovic, O. (2008). From clusters to cluster-based economic development. International Journal of technological learning, innovation and development, 1(3), 375-392.

Ketels, C., Lindqvist, G., \& Sölvell, Ö. (2006). Cluster initiatives in developing and transition economies. Stockholm: Center for Strategy and Competitiveness.

Ketels, C., Lindqvist, G., \& Sölvell, Ö. (2012). Strengthening clusters and competitiveness in Europe. The Role of Cluster Organisations. The Cluster Observatory.

Kragulj, D. 2015. Economics - Basis of microeconomic and macroeconomic analysis. Belgrade, Serbia

Lengyel, I. (2009). Bottom-up regional economic development: competition, competitiveness and clusters. Regional Competitiveness, Innovation and Environment, 13-38. 
Minovic, J., Lazarevic - Moravcevic, M., \& Beraha, I. (2017). Strategic Orientation of SMEs: Empirical Research. Management: Journal Of Sustainable Business And Management Solutions In Emerging Economies, 21(81), 16-26.

Paraušić, V., Cvijanović, D., Mihailović, B., \& Veljković, K. (2014). Correlation between the state of cluster development and national competitiveness in The Global Competitiveness Report of the World Economic Forum 2012-2013. Economic research-Ekonomska istraživanja, 27(1), 662-672.

Parežanin, M., Jednak, S., \& Kragulj, D. (2014). The Influence of the KnowledgeBased Economy on the Competitiveness of European Economies and Businesses. In Innovative Management and Firm Performance (pp. 68-90). Palgrave Macmillan UK.

Porter M (1998). Clusters and the new economics of competitiveness. Harvard Business Review, 77-90.

Porter, M. E. (2001). Regions and the New Economics of Competition. In Scott, A. J. (ed.) Global City-Regions. Trends, Theory, Policy . Oxford University Press, Oxford.

Rakićević, Z., Omerbegović-Bijelović, J., \& Lečić-Cvetković, D. (2016). A model for effective planning of SME support services. Evaluation and program planning, 54, 3040 .

Sosnovskikh, S. (2017). Industrial clusters in Russia: The development of special economic zones and industrial parks. Russian Journal of Economics, 3(2), 174-199.

Stimson, R. J., Stough, R. R., \& Roberts, B. H. (2006). Industry clusters and industry cluster analysis. Regional Economic Development: Analysis and Planning Strategy, 237-277.

Strulik, H., Prettner, K. \& Prskawetz, A. (2013) The past and future of knowledgebased growth. Journal of Economic Growth, 18 (4), 411-437.

Sum, NL. \& Jessop, B. (2013). Competitiveness, the Knowledge-Based Economy and Higher Education. Journal of the Knowledge Economy, 4 (1), 24-44.

Taddeo, R., Simboli, A., Ioppolo, G., \& Morgante, A. (2017). Industrial Symbiosis, Networking and Innovation: The Potential Role of Innovation Poles. Sustainability, 9(2), 169.

Taddeo, R., Simboli, A., Morgante, A., \& Erkman, S. (2017a). The Development of Industrial Symbiosis in Existing Contexts. Experiences From Three Italian Clusters. Ecological Economics, 139, 55-67.

\section{Summary}

The paper is an analysis of knowledge and clusters as drivers of economic development and competitiveness. A theoretical overview of the knowledge-based and clusters 
development is provided. The overview economic development of EU candidate countries is given. EU candidates still have economic issues. Their development is mostly based on macroeconomic level. Correlation between cluster development and competitiveness is analysed. Knowledge and cluster development has an impact on competitiveness, regional and economic development in the EU. However, they are not the key factors in EU candidate countries. Limitation of the paper is a lack of the empirical studies and data of EU candidate countries. 